Kebijakan: Jurnal Ilmu Administrasi

Volume 13, Nomor 1, Januari 2022

E-ISSN: 2656-2820

P-ISSN 1829-5762

\title{
STRATEGI MANAJEMEN PEMASARAN DALAM ERA DIGITAL PADA MASA SEKARANG
}

\author{
Ony Y Djogo \\ Universitas Pasundan YPKP, Kota Bandung, Jawa Barat, Indonesia \\ onydjogo@gmail.com
}

\begin{abstract}
ABSTRAK
Orang sering mempergunakan internet dalam segala bidang dari mulai bekerja, sekolah, kuliah, bahkan belanjapun mela lui intenet a tau disebut juga online. Dimasa sekarang tidak menyurutkan para pedagang atau dengan yang lainnya untuk terus melanjutkan kehidupannya. Denga n a danya internet kita bisa memanfaatkan a tau mengembangkan usahausaha yang sudah menurun akan pandemic, Kemajuan teknologi da lam beberapa tahun terakhir memberi sinyal dunia transisi. Dalam manajemen pemasaran dimasa digital sekarang bukan Itu berarti mengubah toko fisik atau memindahkan toko biasa menjadi toko digital. Kriminal manajemen pemasaran arus memudahkan dalam suatu kualitas yang lebih bagus. Di zaman teknologi dan informasi ini sangatlah penting untuk memahami seberapa jauh kita dapat mencapai tujuan yang di harapkan. Suatu informasi merupakan modal dalam memajukan ilmu di zaman sekarang dan suatu senjata demimembangun suatu Negara di era globalisasi di bidang manajemen pemasaran. Pada masa sekarang masih kurangnya masyarakat akan sadar atau pengusaha dalam manajemen pemasaran, media digital suatu sarana dalam memajukan kegiatannya khususnya dalam bidang pemasaran.
\end{abstract}

Kata kunci: Pemasaran, Manajemen, Digital.

\section{ABSTRACT}

People often use the internet in all fields from work, school, college, even shopping through the internet or also called online. The present does not discourage traders or others from continuing their lives. With the internet, we can take advantage of or develop businesses that have declined due to a pandemic. Technological advances in recent years have signaled a transitional world. In today's digital era marketing management does not mean changing physical stores or moving ordinary stores into digital stores. Criminal management stream marketing facilitates in a better quality. In this age of technology and information it is very important to understand how far we can reach the expected goals. An information is a capital in advancing science today and a weapon for building a country in the era of globalization in the field of marketing management. At the present time there is still a lack of public awareness or entrepreneurs in marketing management, digital media is a means in advancing their activities, especially in the marketing field.

Keywords: Marketing, Management, Digital, Field.

\section{PENDAHULUAN}

Tahun 1970 mulai munculnya Internet dengan diawali oleh Negara Amerika, mulai masuk ke negara Pertengahan 2000 lalu Indonesia terfokus pada teknologi computer.(Sundari \& Sulistyowami, 2021). Tahun 1998 mulai munculnya Google, pada tahun 2000 an mulai berkembangnya Intenet di seluruh penjuru dunia termasuk Indonesia. Dengan adanya internet kita bisa dengan mudah melakukan sesuatu dan membagikan informasi kesemua orang. (Tarbiyah et al., 2021). Sehubungan dengan hal tersebut orang 


\section{Kebijakan: Jurnal Ilmu Administrasi \\ Volume 13, Nomor 1, Januari 2022 \\ E-ISSN: 2656-2820 \\ P-ISSN 1829-5762}

sering mempergunakan internet dalam segala bidang dari mulai bekerja, sekolah, kuliah, bahkan belanjapun melalui intenet atau disebut juga online. Dimasa sekarang tidak menyurutkan para pedagang atau dengan yang lainnya untuk terus melanjutkan kehidupannya. Dengan adanya internet kita bisa memanfaatkan atau mengembangkan usaha-usaha yang sudah menurun akan pandemic (Enjang Suherman \& Rika Uswatun Hasanah, 2020); (Tarbiyah et al., 2021). Kemajuan Dalam bidang ilmu teknologi sudah memasuki pada semua kehidupan juga dalam perdagangan. Sektor ekspor impor sangat penting karena berfungsi sebagai titik bertemunya antara dua belah pihak penjual dan pembeli untuk menyelesaikan transaksi keuangan.(Aynie et al., 2021). Dalam manajemen perdagangan dimasa digital sekarang bukan Itu berarti mengubah toko fisik atau memindahkan toko biasa menjadi toko digital. Kriminal manajemen pemasaran arus memudahkan dalam suatu kualitas yang lebih bagus. (Sidharta \& Sidh, 2014). Bahwa Manajemen Pemasaran dimasa sekarang hanya dengan cara Online, tidak dengan memperbaiki nilai-nilai digital dimasa sekarang, maka akan ditinggalakan sama konsumen (Permata Sari, 2020).

Di zaman teknologi dan informasi ini sangatlah penting untuk memahami seberapa jauh kita dapat mencapai tujuan yang di harapkan. Suatu informasi merupakan modal dalam memajukan ilmu di zaman sekarang dan suatu senjata demi membangun suatu Negara di era globalisasi di bidang manajemen pemasaran. Pada masa sekarang masih kurangnya masyarakat akan sadar atau pengusahadalam manajemen pemasaran, media digital suatu sarana dalam memajukan kegiatannya khususnya dalam bidang pemasaran. (Nasir et al., 2019). Dalam Menjalankan taktik manajemen pemasaran kita harus jelas untuk dimengerti ciri-ciri konsumen loyal pada produk yang dihasilkan dan mempengaruhi atau meyakinkan konsumen dalam suatu produk.(Ekonomi et al., 2018). Di era media dan teknologi canggih, pesan agensi pemasaran terus mengalir, dan banyaknya perusahaan berjuang dalammeningkatkan kinerjanya dengan tidak memakai teori pemasaran dimasa sekarang. Ini adalah teknik pemasaran yang dapat menarik banyak pasar dan pelanggan baru dengan investasi y ang relatif kecil dalam pemasaran web.(Ir.agustina Shinta, 2020). Dalam situasi seperti itu, terutama dalam konteks pandemi (pandemi global), banyaknya perusahaan yang mau tidak mau harus mengubah manajemen pemasaran sendiri dan merevisi strategi pemasaran yang digunakan oleh perusahaan yang dianggap tidak efektif saat itu, Wabah pandemic yang semakin parah. (Lestari \& Saifuddin, 2020).

\section{METODE}

Di lingkungan hidup sehari-hari banyaknya gambaran mengenai situasi dalam ekonomi tidak produktif pada pemanfatan digital dalam bidang ekonomi. Maka dari itu kita harus bisa memanfaatkan usahawan yang baru demi meningkatkan ekonomi dalam mengelola media secara efektif dan efesien.

Ada beberapa Metode yang digunakan dalam melaksanakan penelitian ini, yaitu

1. Metode kualitatif. Secara rinci, kualitatif memberikan ruang bagi peneliti untuk mengkaji secara deskriptif fenomena yang diteliti guna mencapai suatu kebijakan untuk tindakan atau sikap. Tentu saja, dalam riset pemasaran, ini adalahlangkah yang sangat nyamandan mudah.(PermataSari, 2020)

2. Metode pengumpulan data sekunder. Kami mengumpulkan data untuk penelitian ini melalui bukubuku pemasaran, artikel ilmiah, danjurnal, serta situs webyang terkait dengan penelitianini dan yang variabel terikat dan bebasnya sama dengan nama peneliti simpan pilih. (Lestari \& Saifuddin, 2020) 


\section{Kebijakan: Jurnal Ilmu Administrasi \\ Volume 13, Nomor 1, Januari 2022 \\ E-ISSN: 2656-2820 \\ P-ISSN 1829-5762}

3. Metode bantuan, pendampingan merupakan sarana yang sering digunakan dalam kegiatan pemberdayaan masyarakat dalam upaya membantu masyarakat mengembangkan dan melaksanakan tujuan individu dan kelompok. (Bakhri \& Futiah, 2020)

4. Sumber tersebut menggunakan banyak ulasan pelanggan untuk mempelajari tentang strategi pemasaran di salah satu situs perdagangan mereka. (Aynie et al., 2021)

\section{PEMBAHASAN}

Didalam Tahapan ini Team segera memperaktekan berkaitan manajemen pemasaran bersama cara membeli sebuah barang bersama dengan cara online dan lakukan ilmu bagaimana manajemen pemasaran pada sebuah barang atau product di masa digital. Melaksanakan manajemen pemasaran harus adanya bisnis mikro dan menengah, perlunya sebuah kepuasan terhadap pelanggan yang jadi perhatian primer. Manajemen pemasaran interaksi erat bersama dengan mengindentifikasi didalam mencukupi keperluan dan mendefinisikan pemasaran sebagai proses perencanaan. (Sri Sundari, Indriana Sulistyowarni). Dalam upaya pengembangan bisnis ini, peru sahaan menggunakan teknologi yang ada. Pemasaran dimasa sekarang salah satu bentuk untuk mengembangkan bisnis ini, yang dapat kita lakukan adalah mempromosikan produk hemat biaya ini secara online. Contohnya adalah menambahkan produk ke bisnis e-commerce yang sudah ada. Gambar 2 di bawah ini menunjukkan persentase orang yang membeli, menjual, atau hanya browsing online pada tahun 2020, terutama pada kelompok usia 16-64.(Tarbiyah et al., 2021). Konsumen mampu saat pembelian, baik kas maupun transfer bank. Tapi sebagian besar lebih memilih secara kas pembayaran tanpa uang tunai. (Permata Sari, 2020). Shopee Indonesia merupakan salah satu perusahaan pusat perbelanjaan yang dioperasikan oleh Garena, yang kini telah berubah nama menjadi SEA Group. Dengan komunikasi pemasaran dari mulut ke mulut, perusahaan menang dengan biaya rendah dan dampak tinggi. Toko, khususnya produk kecantikan, memiliki eWOM yang memungkinkan konsumen dengan mudah mengumpulkan dan menerima informasi tentang pengalaman berbelanja konsumen lain untuk produk yang akan mereka beli di toko. Pengaruh intensitas membaca ulasan konsumen yang berbeda di Internet pada peningkatan kepercayaan pembeli e-commerce dapat dijelaskan oleh teori pemrosesan informasi. (Aynie et al., 2021)

Pemasaran adalah manajemen dan proses yang memungkinkan individu atau kelompok untuk mencapai apa yang mereka inginkan dan butuhkan melalui setiap aktivitas yang berhubungan dengan menciptakan, menyediakan, dan mempertukarkan nilai produk dengan orang lain, atau dari produsen untuk menyediakan produk atau jasa kepada konsumen. Tujuan pemasaran ini adalah untuk menarik pelanggan baru dengan menjanjikan nilai superior, menetapkan harga yang menarik, dengan mudah menyebarkan produk atau layanan, dan secara ef ektif mempromosikan dan mempertahankan pelanggan yang sudah ada dengan tetap menjaga kepuasan pelanggan. (Ir.agustina Shinta, 2020);(Lestari \& Saifuddin, 2020). Tahap awal pendampingan adalah pendahuluan. Yaitu melalui proses engagement yang diawali dengan pendekatan yang bertujuan untuk menjamin keterbukaan, dukungan dan partisipasi masyarakat. (Bakhri \& Futiah, 2020) 


\section{Kebijakan: Jurnal Ilmu Administrasi \\ Volume 13, Nomor 1, Januari 2022 \\ E-ISSN: 2656-2820 \\ P-ISSN 1829-5762}

\section{SIMPULAN}

Didalam kesimpulan ini kami mampu menggambarkan bagaimana manajemen pemasaran sanggup diterima oleh penduduk. Meningkatnya sebuah corporate dipengaruhi oleh factor Konsumen didalam mengembangkan internet di jaman sekarang. Penelitian ini diharapkan dapat menjadi dasar untuk memahami strategi manajemen pemasaran menggunakan internet dan media sosial yang ada saat ini, serta memberikan wawasan kepada pembaca tentang apa itu pengetahuan manajemen pemasaran. Peneliti berikut diharapkan dapat lebih mendalami pemahaman tentang digital marketing pelaku UMKM. Sangat menarik mendengar survei ini, karena konsumen sudah terbiasa berbelanja online dan sangat menikmatinya. Konsumen benar-benar dapat menghabiskan waktu bersama keluarga, orang dapat bersantai, tetapi masih mampu membeli kebutuhan pokok yang dianggap sebagai cara paling nyaman untuk berbelanja. Dalam hal pembayaran, konsumen merasa memiliki pilihan untuk mendapatkan apa yang mereka inginkan dan berbelanja sesuai keinginan mereka. Itu adalah pembelian online. Pergeseran strategi periklanan dari promosi pemasaran tradisional yang dilakukan oleh para pelaku bisnis selama pandemi COVID-19 ke promosi pemasaran digital adalah positif. Manfaat tersebut antara lain kepraktisan pemasaran, pengurangan biaya operasional perusahaan, dan terutama upaya penganggaran dalam proses periklanan. Ini adalah respon yang lebih cepat kepada konsumen dalam segala hal yang berhubungan dengan mereka.

\section{DAFTAR PUSTAKA}

Aynie, R. Q., Hurriyati, R., \& Dirgantari, P. D. (2021). Strategi pemasaran electronic word of mouth pada e-commerce dalam menghadapi era digital 4.0 di indonesia. Inovasi, 17(1), 136-143. http://journal.feb.unmul.ac.id/index.php/INOVASI/article/view/8483\%0Ahttp://journal.feb.unmul .ac.id/index.php/INOVASI/article/download/8483/1149

Bakhri, S., \& Futiah, V. (2020). Pendampingan dan Pengembangan Manajemen Pemasaran Produk. Jurnal Loyalitas Sosial, 2(2), 59-70.

Ekonomi, F., Muhammadiyah, U., \& Utara, S. (2018). Salman Farisi. 689-705.

Enjang Suherman, \& Rika Uswatun Hasanah. (2020). Analisis Pelatihan Marketplace Bagi Pelaku Usaha Kue Di Masa Pandemik Covid-19 Di Desa Jatiragas. Jurnal Manajemen \& Bisnis Kreatif, 6(1), 98-110. https://doi.org/10.36805/manajemen.v6i1.1202

Ir.agustina Shinta, M. P. (2020). Manajemen Pemasaran : Manajemen Pemasaran Modern. In Management Pemasaran (Vol. 9, Issue 2).

Lestari, P., \& Saifuddin, M. (2020). Implementasi Strategi Promosi Produk Dalam Proses Keputusan Pembelian Melalui Digital Marketing Saat Pandemi Covid'19. Jurnal Manajemen Dan Inovasi (MANOVA), 3(2), 23-31. https://doi.org/10.15642/manova.v3i2.301

Nasir, M., Basalamah, J., \& Kusuma, A. H. P. (2019). Kegiatan E-Marketing Sebagai Bentuk Kewirausahaan Dini Bagi Pelajar. Jurnal Pengabdian Kepada Masyarakat, 1(1), 01-08.

Permata Sari, S. (2020). Strategi Meningkatkan Penjualan Di Era Digital. SCIENTIFIC JOURNAL OF REFLECTION: Economic, Accounting, Management and Business, 3(3), 291-300. https://doi.org/10.5281/zenodo.3930698

Sidharta, I., \& Sidh, R. (2014). Pengukuran Persepsi Manf aat Dan Persepsi Kemudahan Terhadap Sikap 


\section{Kebijakan: Jurnal Ilmu Administrasi}

Volume 13, Nomor 1, Januari 2022

E-ISSN: 2656-2820

P-ISSN 1829-5762

Serta Dampaknya Atas Penggunaan Ulang Online Shopphing Pada E-Commerce. Jurnal Computech \& Bisnis, 8(2), 92-100.

Sundari, S., \& Sulistyowarni, I. (2021). Pemberdayaan Umkm Melalui Digital Marketing.

Tarbiyah, F., Kudus, I., \& Kudus, I. (2021). NCOINS : National Conference Of Islamic Natural Science (2021) PENGEMBANGAN MEDIA PEMBELAJARAN INTERAKTIF BERBASIS APLIKASI ANDROID “SIPERAH ” PADA MATERI. 35-48. 